\title{
Media Kartu Uno Berbasis Multimedia Interaktif pada Kemampuan Kognitif Anak Usia Dini dalam Mengenal dan Berhitung Angka
}

\section{Gusti Ayu Wulandari1 ${ }^{*}$, Didith Pramunditya Ambara²}

1,2 Jurusan Pendidikan Dasar, Universitas Pendidikan Ganesha, Singaraja, Indonesia

\section{AR T I C L E I N F O \\ Article history: \\ Received 03 Mei 2021 \\ Revised 15 Mei 2021 \\ Accepted 17 Juli 2021 \\ Available online 25 Agustus 2021}

Kata Kunci

Kartu Uno, Multimedia Interaktif

Keywords:

Uno Cards, Interactive Multimedia

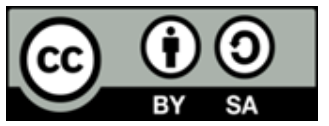

This is an open access article under the CC BY-SA license.

Copyright $(2021$ by Author. Published by Universitas Pendidikan Ganesha.

\begin{abstract}
A B S T R A K
Kesulitan yang dialami guru dalam pembelajaran daring. Guru memerlukan media pembelajaran yang kreatif dan menarik dalam pembelajaran daring. Penelitian ini bertujan untuk menciptakan rancang bangun dan mengetahui validitas media kartu UNO berbasis multimedia interaktif untuk kemampuan kognitif anak usia dini dalam mengenal dan berhitung angka. Jenis penelitian ini adalah penelitian pengembangan (research and development). Subjek penelitian ini berjumlah 5 yang terdiri dari 1 orang ahli isi pembelajaran, 1 orang ahli desain pembelajaran dan ahli media pembelajaran dan 3 orang anak usia dini pada uji perorangan. Data dikumpulkan menggunakan metode kuesioner. Data diolah menggunakan teknik analisis deskriptif kuantitatif. Hasil uji validitas yang dilakukan oleh ahli isi pembelajaran, ahli desain pembelajaran, dan ahli media pembelajaran memperoleh skor $86,45 \%$ dengan kualifikasi baik, serta uji coba perorangan memperoleh skor $92,50 \%$ dengan kualifikasi sangat baik. Jadi dapat dinyatakan bahwa media kartu UNO berbasis multimedia interaktif ini layak digunakan pada kemampuan kognitif anak usia dini dalam mengenal dan berhitung angka. Implikasi dalam penelitian ini adalah media kartu UNO ini dapat menjadi solusi atas kesulitan yang dialami guru dalam pembelajaran daring.
\end{abstract}

\begin{abstract}
A B S T R A C T
This research was conducted based on the difficulties experienced by teachers in online learning. Teachers need creative and interesting learning media in online learning. This study aims to describe the design and determine the validity of interactive multimedia-based UNO card media for early childhood cognitive abilities in recognizing and counting numbers. This type of research is research and development. The subjects of this study were 5 consisting of 1 learning content expert, 1 learning design expert and learning media expert and 3 early childhood children on individual tests. Data were collected using a questionnaire method. The data was processed using quantitative descriptive analysis techniques. The results of the validity tests carried out by learning content experts obtained good qualifications, learning design experts obtained good qualifications, learning media experts obtained good qualifications, and individual trials obtained very good qualifications. So it can be stated that the interactive multimedia-based UNO card media is suitable for use in early childhood cognitive abilities in recognizing and counting numbers. The implication of this research is that the UNO card media can be a solution to the difficulties experienced by teachers in online learning.
\end{abstract}

\section{PENDAHULUAN}

Pendidikan memiliki peran dalam membentuk manusia menjadi pribadi yang lebih baik dan meningkatakan kualitas seorang manusia (Amini \& Suyadi, 2020; Yusnia, 2019). Untuk mewujudkan hal tersebut, maka pendidikan perlu ditanamkan sejak dini untuk mempersiapkannya dimasa mendatang. Poses pendidikan pada anak usia dini harus dapat dipersiapkan dengan baik untuk menunjang kemajuan kecerdasan anak dan mempersiapkan anak untuk masa mendatang (Nofikasari et al., 2019; Oktaviarini, 2017). Maka dari itu periode ini harus dapat dimanfaatkan seoptimal mungkin dengan disesuaikan dengan dunia anak dan memberikan kesempatan kepada anak untuk aktif dan kreatif dengan menerapkan konsep belajar sambil bermain. Terlebih lagi di masa perkembangan teknologi yang pesat sepeti saat ini 
dapat memberikan manfaat yang baik untuk proses pembelajaran. Perkembangan zaman yang semakin canggih dalam bidang teknologi juga membuat kegiatan pembelajaran dalam pendidikan menjadi lebih berkembang. Penggunaan teknologi saat ini telah membuka satu era baru dalam perkembangan media yang digunakan pada proses belajar dan mengajar (K. Novitasari, 2019; Putra \& Hasiana, 2020). Multimedia merupakan salah satu bentuk perkembangan media pembelajaran yang berbentuk digital. Multimedia adalah sebuah media pembelajara yang dapat membantu guru dalam menyampaikan materi, karena multimedia merupakan kombinasi unsur suara, animasi, gambar, dan video yang dimanipulasi secara digital yang dapat menciptaka pembelajaran yang inovatif (Suandi \& Pamungkas, 2019; Y. Novitasari, 2018).

Proses pembelajaran yang baik akan membantu perkembangan anak dalam mempersiapkan dirinya untuk pendidikan selanjutnya. Dalam proses belajar mengajar hendaknya ditekankan pada perkembangan kognitif, melalui pemberian kesempatan kepada anak untuk dalam berbagai aktivitas pembelajaran (Fardiah et al., 2019; Fardiah et al., 2019). Oleh sebab itu kognitif lebih menekankan pada aspek kemampuan yang diwujudkan dengan cara kemampuan merespon terhadap stimulus yang diberikan kepadanya (Khaeriyah et al., 2018; Irsa et al., 2015). Perkembangan kognitif anak akan mempengaruhi kesiapan ke pendidkan selanjutnya untuk bisa membaca, menulis dan berhitung. Berhitung merupakan salah satu kegiatan pembelajaran yang mempengaruhi perkembangan kognitif anak. Berhitung anak usia dini merupakan dasar pengembangan kemampuan matematika yang harus di kembangkan sejak dini (Oktriyani, 2017; Nasution et al., 2019). Metode berhitung adalah bagian dari pelajaran matematika yang sangat dibutuhkan dalam kehidupan sehari-hari, karena berhitung merupakan dasar bagi pengembangan kemampuan matematika maupun kesiapan untuk mengikuti pendidikan selanjutnya (Farihah, 2017; Sari et al., 2020).

Namun pada kenyataannya proses pembelajaran anak usia dini untuk saat ini tidak bisa dilaksanakan dengan leluasa akibat dari pandemi Covid-19 (M. Agustin, 2020; Harahap, 2021). Seperti observasi yang dilakukan di TK Kumara Windu Kencana I Penatih, proses pembelajaran yang dilakukan disana mengalami keterbatasan akibat dari pembelajaran daring. Proses pembelajaran di masa pandemi menjadi monoton karena guru terbatas untuk menggunakan metode dalam pembelajaran. Apalagi anak usia dini sangat suka bermain sehingga membutuhkan media yang menarik dalam pembelajaran. Permainan UNO merupakan permainan yang dapat memotivasi belajar siswa karena media tersebut menarik dab kreatif. Perkembangan teknologi bisa membuat permainan UNO tersebut dapat dikemas secara digital menjadi multimedia yang dapat membuat pembelajaran menarik dan bias digunakan dalam pembelajaran daring. Media kartu UNO berbasis ini perlu dikembangkan untuk bisa dijadikan media pembelajaran pada proses pembelajaran daring, khususnya untuk konsep berhitung.

Berdasarkan permasalahan sebelumnya solusi yang dapat dilakukan dengan mengemas materi pembelajaran dengan menggunakan media kartu UNO berbasis multimedia interaktif dalam mengenal dan berhitung angka anak usia dini untuk meningkatkan hasil belajar serta rasa semangat anak dalam belajar. Multimedia interaktif adalah media yang menyampaikan informasi secara baik dengan menggabungkan bentuk teks, gambar, animasi, dan audio menjadi sebuah aplikasi berdasarkan teori pembelajaran yang digunakan (Kuswanto et al., 2017; Melianti et al., 2020; Mentari \& Rosalina, 2018). Pemberian pembelajaran yang bermakna membantu anak dalam memahami materi dalam pengalaman yang bersifat nyata yang diartikan dengan materi yang dipelajari (Pantiwati, 2016; Setyowati \& Mawardi, 2018). Permainan kartu merupakan media pembelajaran yang mudah dipahami serta menarik bagi anak dan juga bentuk permainan kartu sangatlah mudah untuk dijadikan media pembelajaran yang salah satunya adalah kartu UNO. Permainan kartu UNO merupakan permainan yang menarik sehingga dapat dimainkan oleh segala usia mulai dari anak-anak hingga orang dewasa (Maslina, 2020; Artini et al., 2016). Media pembelajaran dalam bentuk permainan akan menciptakan pembelajaran yang inovatif dan akan membantu perkembangan kogitif anak (Purnamasari \& Mayar, 2019; Fardiah et al., 2019). Proses pembelajaran hendaknya dapat membantu perkembangan kognitif anak agar bisa meningkatnya kemampuan intlektualnya. Mengembangkan suatu media pembelajaran yang berupa sebuah aplikasi kartu UNO dengan materi pembelajaran mengenal dan berhitung angka mampu menjadikan pembelajaran lebih efektif dan peserta didik lebih mudah memahami materi pembelajaran. Aplikasi dikembangkan sesuai dengan KD dan indikator kebutuhan anak yang dapat dioprasikan menggunakan handphone dan laptop. Sehingga penggunaan aplikasi pembelajaran ini dapat digunakan dimanapun dan kapanpun dengan interaksi antara media dan juga pengguna.Penelitian ini didukung oleh penelitian sebelumnya oleh (Estiani et al., 2015) mengenai media kartu UNO merupakan media pembelajaran yang menerapkan konsep bermain untuk menyampaikan materi dalam proses pembelajaran, (Rahmawati et al., 2019) Media kartu UNO efektif untuk meningkatkan motivasi belajar anak untuk belajar, karena permainan kartu UNO mengajak anak untuk melaksanakan proses pembelajaran sambil bermain. Selain itu pembelajaran daring memerlukan media pembelajaran yang variatif untuk membantu melatih anak untuk mengenal angkat 
dan berhitung yang salah satunya bisa menggunakan permainan kartu UNO (Kholida \& Sutama, 2020). Permainan kartu UNO ini dikemas dalam bentuk digital yang dapat diakses melalui HP sehingga lebih fleksibel. Dengan media yang bersifat fleksibel tersebut akan membantu anak dalam proses pembelajaran daring. Penelitian ini bertujan untuk menciptakan rancang bangun dan mengetahui validitas media kartu UNO berbasis multimedia interaktif untuk kemampuan kognitif anak usia dini dalam mengenal dan berhitung angka. Penelitian ini juga bertujuan untuk menciptakan proses pembelajaran yang menarik di masa pandemi yang membatasi guru dalam melaksanakan proses pembelajaran.

\section{METODE}

Jenis penelitian ini adalah penelitian pengembangan (research and development). Produk media kartu UNO pada penelitian ini dikembangkan dengan menggunakan model ADDIE yang terdiri dari lima tahapan yaitu analisis (analyze), perancangan (design), pengembangan (development), implementasi (implementation), evaluasi (evaluation). Rancangan pelaksanaan model ADDIE dapat dilihat pada gambar 1.

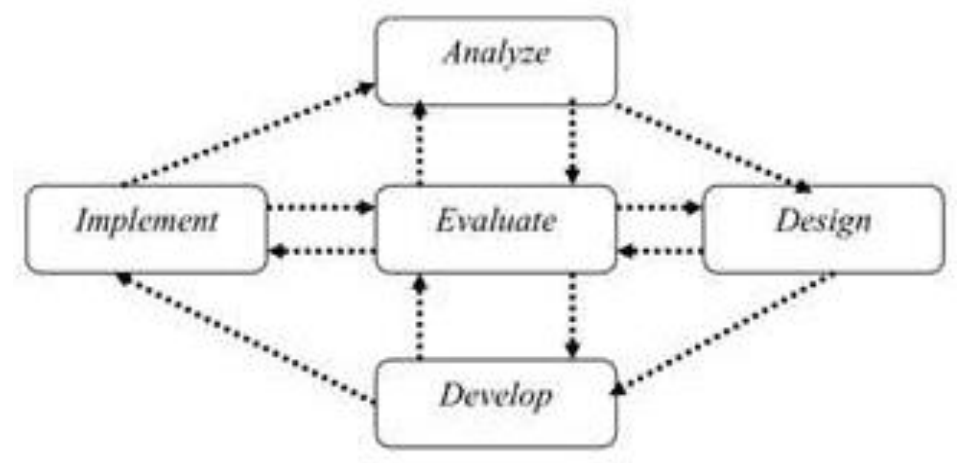

Gambar 1. Tahap Penelitian Model ADDIE (Sumber: Tegeh, dkk., 2014)

Subjek penelitian ini berjumlah 5 yang terdiri dari 1 orang ahli isi pembelajaran, 1 orang ahli desain pembelajaran dan ahli media pembelajaran dan 3 orang anak usia dini kelompok B Kumara Windu Kencana I pada uji perorangan. Ahli isi pembelajaran, ahli desain pembelajaran, dan ahli media pembelajaran merupakan seorang dosen yang mengajar di Jurusan Pendidikan Dasar di Universitas Pendidikan Ganesha. Subjek pada uji coba perorangan menggunakan tiga orang anak kelompok B TK Kumara Windu Kencana I yang terdiri dari anak berkemampuan tinggi, sedang, dan rendah. Metode pengumpulan data yang digunakan pada penelitian ini adalah metode kuesioner. Kuesioner diberikan pada uji validitas yang dilakukan oleh para ahli dan juga uji coba perorangan yang dilakukan oleh anak anak kelompok B TK. Kuisioner yang diberikan kepada subjek digunakan untuk mengumpulkan informasi terkait menentukan kelayakan produk multimedia interaktif. Data yang sudah terkumpul pada kuesioner kemudian diolah dengan teknik analisis deskriptif kuantitatif. Instrumen yang digunakan pada penelitian ini menggunakan kuesioner. Adapun kisi-kisi instrumen yang digunakan untuk mengumpulkan data pada uji validitas dan uji coba perorangan dapat dilihat pada tabel 1, 2, 3 dan 4.

Tabel 1. Kisi - Kisi Instrumen Ahli Isi Pembelajaran

\begin{tabular}{|c|c|c|c|c|}
\hline No. & Aspek & Indikator & Nomor Butir & Jumlah Butir \\
\hline \multirow{2}{*}{1} & \multirow{2}{*}{ Kurikulum } & 1. Tujuan pembelajaran. & 1 & \multirow{2}{*}{2} \\
\hline & & 2. Kesesuaian kompetensi dasar dan indikator. & 2 & \\
\hline \multirow{6}{*}{2} & \multirow{6}{*}{ Materi } & 1. Materi mudah dipahami. & 3 & \multirow{6}{*}{6} \\
\hline & & 2. Ketepatan materi. & 4 & \\
\hline & & $\begin{array}{l}\text { 3. Kesesuaian materi dengan karakteristik } \\
\text { anak. }\end{array}$ & 5 & \\
\hline & & 4. Kebenaran materi. & 6 & \\
\hline & & 5. Kemenarikan materi & 7 & \\
\hline & & 6. Materi didukung dengan media yang tepat. & 8 & \\
\hline \multirow{3}{*}{3} & \multirow{3}{*}{ Kebahasaan } & $\begin{array}{l}\text { 1. Bahasa yang digunakan sesuai dengan } \\
\text { karakteristik anak. }\end{array}$ & 9 & \multirow{3}{*}{3} \\
\hline & & 2. Bahasa yang digunakan mudah dipahami. & 10 & \\
\hline & & 3. Penggunaan bahasa yang tepat dan & 11 & \\
\hline
\end{tabular}




\begin{tabular}{|c|c|c|c|c|}
\hline No. & Aspek & Indikator & Nomor Butir & Jumlah Butir \\
\hline 4 & Evaluasi & $\begin{array}{l}\text { konsisten. } \\
\text { 1. Kejelasan target hasil belajar. }\end{array}$ & 12 & 1 \\
\hline & & Jumlah & & 12 \\
\hline
\end{tabular}

Tabel 2. Kisi - Kisi Instrumen Desain Pembelajaran

\begin{tabular}{|c|c|c|c|c|}
\hline No. & Aspek & Indikator & Nomor Butir & Jumlah Butir \\
\hline \multirow[t]{3}{*}{1} & Tujuan & 1. Kejelasan tujuan pembelajaran. & 1 & 1 \\
\hline & & 1. Memberikan penarikan perhatian & 2 & \\
\hline & & $\begin{array}{l}\text { 2. Memberikan kesempatan pada anak untuk } \\
\text { belajar mandiri. }\end{array}$ & 3 & \\
\hline \multirow[t]{3}{*}{2} & Strategi & 3. Memberikan petunjuk belajar. & 4 & 5 \\
\hline & & $\begin{array}{l}\text { 4. Penyampaian materinya memberikan } \\
\text { langkah-langkah yang logis. }\end{array}$ & 5 & \\
\hline & & 5. Penyampaian materi yang menarik. & 6 & \\
\hline \multirow[t]{2}{*}{3} & Evaluasi & $\begin{array}{l}\text { 1. Diberikan evaluasi untuk mengukur } \\
\text { kemampuan anak. }\end{array}$ & 7 & 2 \\
\hline & & 2. Memberikan umpan balik hasil evaluasi. & 8 & \\
\hline & & Jumlah & & 8 \\
\hline
\end{tabular}

Tabel 3. Kisi - Kisi Instrumen Media Pembelajaran

\begin{tabular}{|c|c|c|c|c|}
\hline No. & Aspek & Indikator & Nomor Butir & Jumlah Butir \\
\hline \multirow{7}{*}{1} & \multirow{6}{*}{ Desain Pesan } & 1. Desain tampilan. & 1 & \multirow[t]{6}{*}{ ( } \\
\hline & & $\begin{array}{l}\text { 2. Penggunaan gambar dan animasi yang } \\
\text { mendukung pembelajaran. }\end{array}$ & 2 & \\
\hline & & $\begin{array}{l}\text { 3. Komposisi dan kombinasi warna yang tepat } \\
\text { serta serasi. }\end{array}$ & 3 & \\
\hline & & 4. Keterbacaan teks. & 4 & \\
\hline & & $\begin{array}{l}\text { 5. Penggunaan jenis huruf, ukuran dan spasi } \\
\text { tuisan yang tepat. }\end{array}$ & 5 & \\
\hline & & 6. Media dapat memonitor kegiatan anak. & 6 & \\
\hline & \multirow{3}{*}{ Pengoprasian } & 1. Kemudahan penggunaan media. & 7 & \multirow{3}{*}{3} \\
\hline \multirow[t]{2}{*}{2} & & 2. Dukungan musik yang sesuai media. & 8 & \\
\hline & & 3. Pengggunaan sound effect yang tepat & 9 & \\
\hline \multirow{3}{*}{3} & \multirow{3}{*}{$\begin{array}{c}\text { Ketepatan, } \\
\text { Teknik, } \\
\text { Kejelasan }\end{array}$} & 1. Konsisten dengan tema. & 10 & \multirow{3}{*}{3} \\
\hline & & $\begin{array}{l}\text { 2. Media yang digunakan dapat membangkitkan } \\
\text { motivasi anak. }\end{array}$ & 11 & \\
\hline & & $\begin{array}{l}\text { 3. Media yang digunakan dapat membantu } \\
\text { pemahaman materi. }\end{array}$ & 12 & \\
\hline & & Jumlah & & 12 \\
\hline
\end{tabular}

Tabel 4. Kisi - Kisi Instrumen Uji Coba Perorangan

\begin{tabular}{|c|c|c|c|c|}
\hline No. & Aspek & Indikator & Nomor Butir & Jumlah Butir \\
\hline \multirow{4}{*}{1} & \multirow{4}{*}{ Desain Pesan } & 1. Kemenarikan desain produk. & 1 & \multirow{4}{*}{4} \\
\hline & & 2. Kejelasan gambar. & 2 & \\
\hline & & 3. Keterbacaan teks. & 3 & \\
\hline & & 4. Kejelasan suara atau audio. & 4 & \\
\hline \multirow{2}{*}{2} & \multirow{2}{*}{ Materi } & 1. Kemudahan pemahaman materi. & 5 & \multirow{2}{*}{2} \\
\hline & & 2. Kejelasan uraian materi. & 6 & \\
\hline 3 & Pengoperasian & 1. Kemudahan pengoperasian. & 7 & 1 \\
\hline \multirow[t]{2}{*}{4} & Motivasi & 1. Media memberikan semangat. & 8 & 1 \\
\hline & & Jumlah & & 8 \\
\hline
\end{tabular}

(Sumber: Suartama, 2016 dengan modifikasi dari peneliti) 
Untuk Kriteria yang digunakan untuk memberikan makna dan pengambilan keputusan dapat dilihat pada tabel 5 .

Tabel 5. Konversi Tingkat Pencapaian dengan Skala 5

\begin{tabular}{cccc}
\hline No. & Tingkat Pencapaian (\%) & Kualifikasi & Keterangan \\
\hline 1 & $90-100$ & Sangat Baik & Tidak Perlu Direvisi \\
2 & $75-89$ & Baik & Sedikit Revisi \\
3 & $65-79$ & Cukup & Direvisi Secukupnya \\
4 & $55-64$ & Kurang & Banyak Hal Yang Direvisi \\
5 & $1-54$ & Sangat Kurang & Diulang Membuat Produk \\
\hline
\end{tabular}

(Sumber: Agung, 2014)

\section{HASIL DAN PEMBAHASAN}

Hasil

Pada bagian ini menyajikan rancang bangun dan validitas produk. Rancang bangun menyajikan proses pengembangan produk yang dikembangkan menggunakan model pengembangan ADDIE. Sementara validitas menyajikan hasil kuesioner yang diberikan kepada subjek dalam penelitian ini yaitu para ahli dan juga anak Kelompok B TK Kumara Windu Kencana I Penatih untuk mengetahui tingkat kelayakan produk. Ada banyak model pengembangan yang dapat digunakan yang dapat disesuaikan dengan produk yang akan dibuat. Produk media kartu UNO berbasis multimedia interaktif ini dikembangkan dengan menggunakan model pengembangan ADDIE yang meliputi tahapan analisis (analyze), tahap perancangan (design), tahap pengembangan (development), tahap implementasi (implementation), dan tahap evaluasi (evaluation). Model pengembangan ADDIE ini digunakan karena tersusun dengan urutan yang sistematis dan cocok untuk mengembangkan produk multimedia (I. M. Tegeh et al., 2014). Tahap pertama adalah analisis. Pada kegiatan tahap analisi kebutuhan guru dan dalam pembelajaran ini, dilakukan untuk mengetahui kebutuhan karakteristik anak, serta menganalisis media pembelajaran yang nantinya akan diajarkan disekolah. Dari hasil penganalisis materi ajar serta karakteristik anak nantinya dapat menghasilkan suatu produk berupa multimedia interaktif atau media pembelajaran yang memiliki inovasi serta minat anak untuk lebih giat dalam belajar. Selain itu masa pandemi menyulitkan guru dalam menyampaikan materi dan meaksankan proses pembelajaran. Hal tersebut membuat guru harus menggukan media pembelajaran yang inovatif dan enjadi solusi atas permasalahan tersebut.

Tahap kedua adalah desain. Pada tahap kegiatan perancangan ini, dilakukan dalam pemilihan suatu materi ajar dalam produk yang nantinya akan disesuaikan dengan karakteristik anak serta kemampuan kompetensi yang dicapai, strategi pembelajaran, bentuk serta metode asesmen dan evaluasi pembelajaran. Pada tahap perancangan ini dibagi menjadi dua yaitu perancangan internal dan eksternal. Perancangan internal adalah perancangan yang ada didalam sistem nantinya berpengaruh terhadap pembuatan produk ini seperti desain interface yang meliputi warna, gambar, tulisan, tata letak, untuk menarik minat peserta didik dalam belajar dan audio berupa penggunaan back sound dalam produk ini berpengaruh untuk memberi kesan suasana saat anak menggunakan atau memainkan media. Sementara perancangan eksternal adalah perancangan yang ada diluar sistem dan mendukung dalam pembuatan produk ini seperti memilih alat untuk membuat media yaitu laptop, smartphone untuk merekam dubbing, dan unity angine yang membantu merancang tampilan serta pembuatan suatu program. Disamping itu peneliti juga membuat storyboard dan flowchart yang digunakan sebagai pedoman dalam mengembangkan produk. Tahap ketiga adalah pengembangan. Pada tahap pengembangan ini, media yang dihasilkan sesuai dengan rancangan yang ada pada storyboard dan flowchart. Sama seperti tahap perancangan, dalam proses pengembangan media ini terdiri dari pengembangan internal dan pengembangan media secara ekternal. Pengembangan internal meliputi pemilihan dan menyeleksi unsurunsur yang digunakan dalam media seperti gambar, warna, animasi, suara, dan teks. Sementara pengembangan eksternal lebih kepada pemilihan alat yang digunakan untuk membuat dan menggunakan media. Pada tahap keempat yaitu implementasi. Pada tahap implementasi ini peneliti melakukan uji validitas untuk menentukan kelayakan produk. Validasi produk ini dilakukan oleh para ahli yaitu ahli isi pembelajaran, ahli dalam desain pembelajaran, ahli dalam media pembelajaran, dan uji coba perorangan.

Pada tahap kelima yaitu evaluasi. Pada kegiatan tahap evaluasi ini, dilakukan penilaian evaluasi mengenai produk yang telah validitas oleh para ahli serta uji perorangan, uji kelompok kecil, dan uji lapangan. Tahap akhir ini menggunakan evaluasi secara formatif. Tahap evaluasi ini dilakukan untuk menyempurnakan produk agar lebih baik daripada sebelumnya. Adapun hasil akhir dari pengembangan media kartu UNO ini yaitu sebagai berikut. Isi pembelajaran, ahli media pembelajaran, ahli desain 
pembelajaran dan anak kelompok B pada uji coba perorangan. Adapun hasil validitas dari media kartu UNO dapat dilihat pada tabel 6 .

Tabel 6. Persentase Hasil Validitas Media UNO

\begin{tabular}{clcc}
\hline No & \multicolumn{1}{c}{ Subjek Uji Coba } & Hasil Validitas (\%) & Kualifikasi Persentase \\
\hline 1. & Uji Ahli Isi Pembelajaran & 89,58 & Baik \\
2. & Uji Ahli Desain Pembelajaran & 85,42 & Baik \\
3. & Uji Ahli Media Pembelajaran & 84,37 & Baik \\
4. & Uji Coba Perorangan & 92,50 & Sangat Baik \\
\hline
\end{tabular}

Berdasarkan tabel 06 persentase hasil uji ahli isi pembelajaran diperoleh hasil 89,58 \% termasuk kualifikasi baik. Hasil uji ahli desain pembelajaran diperoleh hasil 85, $42 \%$ termasuk kualifikasi baik. Hasil uji ahli media pembelajaran diperoleh hasil 84,37 \% termasuk kualifikasi baik. Dan hasil uji coba perorangan diperoleh hasil 92,50 \% termasuk kualifikasi sangat baik. Hasil analisis menunjukkan media pembelajaran kartu UNO berbasis multimedia interaktif valid dan layak untuk diterapkan dalam proses pembelajaran. Penelitian ini mengembangkan media pembelajaran kartu UNO berbasis multimedia interaktif dikarenakan sistem pembelajaran dilakukan secara daring dalam mengenal dan berhitung angka untuk anak usia dini merupakan materi pembelajaran yang sulit diterapkan tanpa adanya bahan ajar dan penjelasan langsung oleh guru kepada peserta didik, minimnya interaksi antara guru dengan anak dan kurang adanya penggunaan media pembelajaran yang inovatif sehingga pembelajaran secara daring cenderung lebih monoton bagi anak. Maka dari itu dikembangkan suatu media pembelajaran berupa aplikasi yang lengkap berisi materi pembelajaran, audio, interaktivitas, dan game yang dikemas dengan menarik untuk digunakan anak dalam mempelajari materi mengenal dan berhitung anak usia dini. Pengembangan ini sejalan dengan pendapat (Firdaus, dkk, 2012) mengenai multimedia sebagai pemanfaatan media komputer dalam pengembangan teks, animasi, suara dapat meningkatkan rasa ingin tahu anak dalam materi yang dibelajarkan.

Hasil uji validitas yang dilakukan oleh ahli isi pembelajaran memperoleh kualifikasi baik. Produk media kartu UNO berbasis multimedia interaktif ini memiliki materi yang mudah dimengerti dan tampilan yang menarik. Media pembelajaran yang menarik adalah salah satu stimulus positif yang bermanfaat dalam perkembangan anak (Rosmiyati \& Wahyuni, 2018; Firdania et al., 2016). Melalui media pembelajaran yang tepat anak dapat terbantu untuk memahami materi yang disampaikan oleh guru (Anggraini et al., 2019; Fitri \& Karlimah, 2018). Proses pembelajaran yang dilakukan untuk anak usia dini perlu mendapat perhatian khusus, karena pembelajaran pada anak usia dini akan mempengaruhi perkembanganya. Sehingga pendidikan anak usia dini adalah masa yang sangat baik bagi guru untuk membentuk konsep dan mempersiapkannya untuk pendidikan selanjutnya. Hasil uji validitas yang dilakukan oleh ahli desain pembelajaran memperoleh kualifikasi baik. Media kartu UNO berbasis multimedia interaktif ini diaplikasikan berdasarkan analisis situasi pembelajaran yang disusun dalam RPP. Analisis situasi pembelajaran sangat penting dilakukan guna untuk menentukan strategi pembelajaran (Bastian, 2019; Agustin et al., 2021). Sebagai guru yang profesional, guru perlu mempersiapkan pembelajaran dengan baik, tentunya disesuaikan berdasarkan kebutuhan anak dan situasi pembelajaran. Dengan hal itu guru dapat menentukan strategi pembelajaran dan guru lebih siap untuk melaksanakan proses pembelajaran

Hasil uji validitas yang dilakukan oleh ahli media pembelajaran memperoleh kualifikasi baik. Media kartu UNO berbasis multimedia interaktif ini dikembangkan dengan visual yang menarik. media pembelajaran yang menarik akan memberikan pengaruh positif pada proses pembelajaran seperti dapat memotivasi siswa dalam belajar (Rosyida, 2017). Media pembelajaran adalah komponen penting dalam proses pembelajaran yang perlu dipersiapkan dengan sebaik mungkin. Media pembelajaran memegang kunci keberhasilan guru dalam mencapai tujuan pembelajaran, karena media pembelajaran menjadi sarana guru untuk memyampaikan materi pembelajaran. Hasil uji validitas yang dilakukan pada tahap uji coba perorangan memperoleh kualifikasi baik. Media kartu UNO berbasis multimedia interaktif ini membuat siswa menjadi antusias dalam belajar. Media pembelajaran yang menarik memiliki pengaruh positif kepada anak sepeti meningkatkan motivasinya untuk belajar (Rosmiyati \& Wahyuni, 2018; D. A. Sari \& Nurjanah, 2020). Media pembelajaran berperan memberikan stimulus kepada anak untuk dapat memahami materi yang disampaikan oleh guru. Anak usia dini sangat peka terhadap stimulus yang diberikan, sehingga hal tersebut bisa dimanfaatkan oleh guru untuk memberikan konsep dasar yang kuat bagi anak.

Temuan ini diperkuat dengan penelitian sebelumnya yang menyatakan media kartu UNO merupakan media pembelajaran yang menerapkan konsep bermain untuk menyampaikan materi dalam proses pembelajaran (Estiani et al., 2015), Media kartu UNO efektif untuk meningkatkan motivasi belajar 
anak untuk belajar (Rahmawati et al., 2019). Permainan kartu UNO membantu melatih anak untuk mengenal angkat dan berhitung yang salah satunya bisa menggunakan permainan kartu UNO (Kholida \& Sutama, 2020). Media interaktif dapat menarik minat belajar siswa (Putra \& Hasiana, 2020; Yuniarni et al., 2020). Dari pembahasan diatas, media kartu UNO berbasis multimedia interaktif valid dan layak diterapkan pada proses pembelajaran daring selama pandemic Covid-19. Keterbatasan pada penelitian ini yaitu pada tahap pelaksanaan uji efektivitas yang tidak bisa dilaksanakan akibat dari pembatasan sosial, sehingga penelitian ini hanya sampai pada uji coba perorangan. Selain itu media ini berbentuk digitas dan memerlungkan perangkat digital seperti handphone untuk dapat menggunakan dan mengaksesnya. Implikasi dalam penelitian ini adalah media kartu UNO dapat menjadi solusi atas kesulitan yang dialami peserta didik, guru, dan sekolah dalam pembelajaran secara daring. Media kartu UNO ini dapat membantu guru untuk membuat proses pembelajaran menjadi lebih kreatif dan menarik, sehingga dapat meningkatka motivasi belajar anak. Media kartu UNO memudahkan anak dalam belajar dan memahami materi pembelajaran yang diajarkan. Kartu UNO bagi sekolah dapat menambah variasi media pembelajaran. Media kartu UNO ini sangat bermanfaat dalam pembelajaran daring karena dapat digunakan kapanpun dan dimanapun.

\section{SIMPULAN}

Hasil analisis uji ahli isi pembelajaran memperoleh kualifikasi baik, ahli desain pembelajaran memperoleh kualifikasi baik, ahli media pembelajaran memperoleh kualifikasi baik, dan uji coba perorangan memperoleh kualifikasi sangat baik. Jadi dapat dinyatakan bahwa media kartu UNO berbasis multimedia interaktif ini layak digunakan pada kemampuan kognitif anak usia dini dalam mengenal dan berhitung angka.

\section{DAFTAR RUJUKAN}

Agung, A. A. G. (2014). Metodologi Penelitian Pendidikan. Aditya Media Publishing.

Agustin, M. (2020). Tipikal Kendala Guru PAUD dalam Mengajar pada Masa Pandemi Covid 19 dan Implikasinya. Jurnal Obsesi: Jurnal Pendidikan Anak Usia Dini, 5(1), 334-345. https://doi.org/10.31004/obsesi.v5i1.598.

Agustin, R., Nurmalia, \& Noviardila, I. (2021). Peranan Media Interaktif Animasi Terhadap Minat Belajar Pada Mata Pelajaran Bahasa Indonesia Pada Siswa Kelas IV SD Negeri 019 Tanjung Sawit Kecamatan Tapung Kabupaten Kampar Pembelajaran 2020/2021. Jurnal Pendidikan Dan Konseling (Jpk), 3(1), 71-79. https://doi.org/10.31004/jpdk.v3i1.1385.

Amini, N., \& Suyadi, S. (2020). Media Kartu Kata Bergambar Dalam Meningkatkan Kemampuan Kosakata Anak Usia Dini. PAUDIA : Jurnal Penelitian Dalam Bidang Pendidikan Anak Usia Dini, 9(2), 119129. https://doi.org/10.26877/paudia.v9i2.6702.

Anggraini, V., Yulsyofriend, Y., \& Yeni, I. (2019). Stimulasi Perkembangan Bahasa Anak Usia Dini Melalui Lagu Kreasi Minangkabau Pada Anak Usia Dini. Pedagogi : Jurnal Anak Usia Dini Dan Pendidikan Anak Usia Dini, 5(2), 73. https://doi.org/10.30651/pedagogi.v5i2.3377.

Artini, N. P. W. D., Suadnyana, I. N., \& Wiarta, I. W. (2016). Penerapan Metode Bermain Berbentuk Media Kartu Angka Bergambar Untuk Meningkatkan Kemampuan Kognitif PAUD Kusuma 2. E-Journal Pendidikan Anak Usia Dini Universitas Pendidikan Ganesha, 4(1). https://doi.org/10.23887/paud.v4i1.7532.

Bastian, B. (2019). Analisis Keterampilan Dasar Mengajar Guru Dalam Melaksanakan Pembelajaran Di Sekolah Dasar. JURNAL PAJAR (Pendidikan Dan Pengajaran), 3(6), 1357. https://doi.org/10.33578/pjr.v3i6.7899.

Christianti, M. (2015). Kemampuan Mengenal Huruf Anak Usia Dini Melalui Multimedia Pembelajaran Interaktif. Prosiding Seminar NasionalPendidikanVokasidalamRangka Dies Natalis Ke-54 FT UNY.

Dora Irsa. (2015). Perancangan Aplikasi Game Edukasi Pembelajaran Anak Usia DIni menggunakan Linier Congruent Method (LCM) Berbasis Android. Jurnal Informatika Global, 6 No. 1 Ma(1), 7-14. https://doi.org/10.36982/jiig.v6i1.4.

Estiani, W., Widiyatmoko, A., \& Sarwi. (2015). Pengembangan Media Permainan Kartu Uno Untuk Meningkatkan Pemahaman Konsep Dan Karakter Siswa Kelas VIITema Optik. Unnes Science Education Journal, 4(1), 711-719. https://doi.org/10.15294/usej.v4i1.4974.

Fardiah, Murwani, S., \& Dhieni, N. (2019). Meningkatkan Kemampuan Kognitif Anak Usia Dini melalui Pembelajaran Sains. Jurnal Obsesi: Jurnal Pendidikan Anak Usia Dini, 4(1), 133. https://doi.org/10.31004/obsesi.v4i1.254. 
Farihah, H. (2017). Mengembangkan Kemampuan Berhitung Anak Usia Dini Melalui Kegiatan Bermain Stick Angka. Jurnal Teladan, $2(1), \quad$ 1-20. http://journal.unirow.ac.id/index.php/teladan/article/view/16\%0A.

Firdania, M. S., Tursina, \& Sastypratiwi, H. (2016). Aplikasi CAI berbasis multimedia untuk pengenalan bagian tubuh manusia pada anak usia dini. Jurnal Sistem Dan Teknologi Informasi, 4(1), 1-5. http://jurnal.untan.ac.id/index.php/justin/article/view/13124.

Fitri, N. A., \& Karlimah. (2018). Pengembangan Media Pop-Up Book Kubus dan Balok untuk Siswa Kelas V Sekolah Dasar. PEDADIDAKTIKA: Jurnal Ilmiah Pendidikan Guru Sekolah Dasar, 5(4), 226-239. https://ejournal.upi.edu/index.php/pedadidaktika/article/view/13196/8502.

Harahap, S. A. (2021). Problematika Pembelajaran Daring dan Luring Anak Usia Dini bagi Guru dan Orang tua di Masa Pandemi Covid 19. Jurnal Obsesi : Jurnal Pendidikan Anak Usia Dini, 5(2), 1825-1836. https://doi.org/10.31004/obsesi.v5i2.1013.

Jabri, U., Sukaryadi, A., Andika, Amin, S. Y., Arni, Pairi, M. S., Faika, N., M, N. I., Supri, Yuneda, Mahmud, Misna, Sumi, Rosminah, \& Elihami. (2020). Media Pembelajaran Pop Up Book Kelas V SDN 181 Curio Yang Kreatif Dan Inovatif. Maspul Journal of Community Empowerment, 2(2), 34-39. https://ummaspul.e-journal.id/pengabdian/article/view/784.

Khaeriyah, E., Saripudin, A., \& Kartiyawati, R. (2018). Penerapan Metode Eksperimen Dalam Pembelajaran Sains Untuk Meningkatkan Kemampuan Kognitif Anak Usia Dini. AWLADY: Jurnal Pendidikan Anak, 4(2), 102. https://doi.org/10.24235/awlady.v4i2.3155.

Kholida, A., Sutama, I. W., \& Suryadi, S. (2020). Pengembangan Alat Permainan Kartu U-Kids (Uno Kids) Untuk Menstimulasi Kecerdasan Logis-Matematis Anak Usia 5-6 Tahun. Cakrawala Dini: Jurnal Pendidikan Anak Usia Dini, 11(2), 76-87. https://doi.org/10.17509/cd.v11i2.24854.

Kuswanto, J., Walusfa, Y., Artikel, S., Korespondensi, A., Ratu Penghulu No, J., Sari, K., Baru, T., Raja Tim, B., Ogan Komering Ulu, K., \& Selatan, S. (2017). Pengembangan Multimedia Pembelajaran pada Mata Pelajaran Teknologi Informasi dan Komunikasi Kelas VIII. Innovative Journal of Curriculum and Educational Technology IJCET, 6(2), 58-64. https://doi.org/10.15294/ijcet.v6i2.19335.

Maslina, A. S. A. A. (2020). Pengembangan Bahan Ajar Ipa Dengan Media Audio Visual Pada Tema Selamatkan Makhluk Hidup Di Pendidikan Dasar. In Jurnal JPSD (Jurnal Pendidikan Sekolah Dasar) (Vol. 7, Issue 1). https://doi.org/10.12928/jpsd.v7i1.14467.

Melianti, E., Risdianto, E., \& Swistoro, E. (2020). Pengembangan Media Pembelajaran Berbasis Multimedia Interaktif Menggunakan Macromedia Director Pada Materi Usaha Dan Energi Kelas X. Jurnal Kumparan Fisika, 3(1), 1-10. https://doi.org/10.33369/jkf.3.1.1-10.

Mentari, T. A. S., \& Rosalina, L. (2018). Penggunaan Media Pembelajaran Multimedia Interaktif Untuk Meningkatkan Aktivitas Dan Hasil Belajar Mahasiswa Pada Mata Kuliah Rias Wajah Karakter Foto/TV/Film Program Studi Pendidikan Tata Rias dan Kecantikan Jurusan Tata Rias Dan Kecantikan FPP UNP. Journal of Education Scienties, 2(2), 194-199. http://lppm.ojs.unespadang.ac.id/index.php/UJES.

Nasution, N., Yaswinda, Y., \& Maulana, I. (2019). Analisis Pembelajaran Berhitung melalui Media Prisma Pintar pada Anak Usia Dini. Jurnal Obsesi: Jurnal Pendidikan Anak Usia Dini, 4(1), 240. https://doi.org/10.31004/obsesi.v4i1.311.

Novitasari, K. (2019). Penggunaan Teknologi Multimedia Pada Pembelajaran Literasi Anak Usia Dini. Jurnal Golden Age, 3(01), 50. https://doi.org/10.29408/goldenage.v3i01.1435.

Novitasari, Y. (2018). Analisis Permasalahan "Perkembangan Kognitif Anak Usia Dini". PAUD Lectura: $\begin{array}{lllll}\text { Jurnal Pendidikan Anak } & \text { 82-90. }\end{array}$ https://doi.org/10.31849/paudlectura.v2i01.2007.

Oktaviarini, N. (2017). Pengembangan Media Pembelajaran Pop-Up Book Tema Lingkungan Dan Alam Sekitar Untuk Siswa Kelas Iv Sd Di Kabupaten Blitar Nourma. Jurna Pena Sd, 03(01), 70-87. https://doi.org/10.29100/jpsd.v3i01.919.

Oktriyani, N. (2017). Peningkatan Kemampuan Berhitung Anak Usia Dini Melalui Permainan Lingkaran Angka Di Taman Kanak- Kanak Qatrinnada Kecamatan Koto Tangah Padang. PAUD Lectura: Jurnal Pendidikan Anak Usia Dini, 1(1), 83-96. https://doi.org/10.31849/paudlectura.v1i1.510.

Pantiwati, Y. (2016). Hakekat Asesmen Autentik Dan Penerapannya Dalam Pembelajaran Biologi. Jurnal Edukasi Matematika Dan Sains, 1(1), 18. https://doi.org/10.25273/jems.v1i1.773.

Purnamasari, Y., \& Mayar, F. (2019). Manajemen Pengembangan Kreativitas Kognitif Dan Bahasa Anak Usia Dini Di Paud "Handayani" Skb Kendal. Jurnal Pendidikan Tambusai, 151, 10-17.

Putra, P. A., \& Hasiana, I. (2020). Mengembangkan Kemampuan Membaca Anak Usia Dini Dengan Multimedia Interaktif. Incrementapedia: Jurnal Pendidikan Anak Usia Dini, 2(02), 19-24. https://doi.org/10.36456/incrementapedia.vol2.no02.a3016. 
Rahmawati, R., Muttaqin, M., \& Listiawati, M. (2019). Peran Permainan Kartu Uno Dalam Meningkatkan Keterampilan Berpikir Kritis Siswa. Jurnal Program Studi Pendidikan Biologi, 9(2), 64-75. https://doi.org/10.15575/bioeduin.v9i2.6221.

Rosmiyati, \& Wahyuni, S. (2018). Meningkatkan Kemampuan Mengenal Konsep Bilangan Anak Usia 4-5 Tahun dengan Bermain Kartu Domino di PAUD Nurjannah Pekanbaru. PAUD Lectura: Jurnal Pendidikan Anak Usia Dini, 76-85. https://doi.org/10.31849/paud-lectura.v2i02.2517.

Rosyida, S. (2017). Multimedia Interaktif sebagai Media Pembelajaran Tentang Pengenalan Vitamin yang Terkandung di Dalam Buah. Teknik Informatika Stmik Antar Bangsa, 3(1), 17-23. https://doi.org/10.51998/jti.v3i1.125.

Sari, D. A., \& Nurjanah, A. L. (2020). Hubungan Game Online dengan Perkembangan Emosional Anak Usia 5-6 Tahun. Jurnal Obsesi : Jurnal Pendidikan Anak Usia Dini, 4(2), 994. https://doi.org/10.31004/obsesi.v4i2.344.

Sari, N. M., Yetti, E., \& Hapidin. (2020). Pengembangan Media Permainan Mipon's Daily untuk Meningkatkan Kemampuan Berhitung Anak. Jurnal Obsesi : Jurnal Pendidikan Anak Usia Dini, 4(2), 831. https://doi.org/10.31004/obsesi.v4i2.428.

Setyowati, N., \& Mawardi, M. (2018). Sinergi Project Based Learning dan Pembelajaran Bermakna untuk Meningkatkan Hasil Belajar Matematika. Scholaria: Jurnal Pendidikan Dan Kebudayaan, 8(3), 253263. https://doi.org/10.24246/j.js.2018.v8.i3.p253-263.

Suandi, A., \& Pamungkas, P. D. A. (2019). Multimedia Interaktif Pembelajaran Ips Kelas 7 Berbasis Android Pada Mts Al-Wasliyah Jakarta Timur. JIPI (Jurnal Ilmiah Penelitian Dan Pembelajaran Informatika), 4(2), 66. https://doi.org/10.29100/jipi.v4i2.1087.

Suartama, I. K. (2016). Evaluasi dan Kriteria Kualitas Multimedia Pembeajaran (Issue January 2016). Universitas Pendidikan Ganesha.

Susanto, Dewi, N. R., \& Irsadi, A. (2013). Pengembangan Multimedia Interaktif dengan Education Game pada Pembelajaran IPA Terpadu Tema Cahaya untuk Siswa SMP/MTs. Unnes Science Education Journal, 2(1). https://doi.org/10.15294/USEJ.V2I1.1829.

Tegeh, I. M. dkk. (2014). Model Penelitian Pengembangan. Graha Ilmu.

Tegeh, I. M., Jampel, I. N., \& Pudjawan, K. (2014). Model Penelitian Pengembangan. Graha Ilmu.

Yuniarni, Sari, \& Atiq. (2020). Pengembangan Multimedia Interaktif Video Senam Animasi Berbasis Budaya Khas Kalimantan Barat. Jurnal Obsesi: Jurnal Pendidikan Anak Usia Dini, 4(1). https://doi.org/10.31004/obsesi.v4i1.331.

Yusnia, Y. (2019). Penggunaan Media Video Scribe Dalam Pembelajaran Literasi Sains Untuk Mahasiswa PGPAUD. Cakrawala Dini: Jurnal Pendidikan Anak Usia Dini, 10(1), 71-75. https://doi.org/10.17509/cd.v10i1.17436. 